\title{
How long do Seeds retain their Vitality?
}

$\mathrm{T}^{\mathrm{n}}$ HE idea of seeds germinating after a lapse of many centuries rarely fails to appeal to the imagination. Probably that is why so many inaccurate and fantastic statements have been made regarding this subject, with which $\mathrm{Mr}$. J. H. Turner has recently dealt in an article entitled "The Viability of Seeds" (Kew Bulletin, No. 6, 1933. London: H.M. Stationery Office. 1s. net). From earliest times people have wondered how long seeds for field and herb garden would keep fresh. Theophrastus, writing about 320 B.c., mentions that "Of seeds some have more vitality than others as to keeping; among the more vigorous ones are coriander, beet, leek, cress, mustard, rocket, savory. . . .' Little was known, however, about the vitality of seeds of wild plants until De Candolle, in 1832, concluded that seeds of many species remained viable in the soil for considerable periods.

"The average life of seeds, as of plants, varies greatly with the different families, genera and species, but there is no relation between the longevity of plants and the viable period of the seeds they bear. Some seeds retain their power of germination for a few days only, such as the willows and poplars, others remain viable for months or even a considerable number of years." The factors which produce a capacity for sustained vitality are still imperfectly understood, but it is known that, under suitable conditions, seeds of 'macrobiotic' families, notably Leguminosæ, Malvaceæ, Myrtaceæ, Nymphæaceæ, etc. may remain viable from fifteen to more than a hundred years.

Only a limited number of cultivated plants produce seeds which retain their vitality for any length of time when buried in the soil, but those of weeds are capable of living for extended periods, and when deeply buried are better preserved as a result of the more equable conditions. The appearance of plants from dormant seeds when ground is freshly turned up is well known, and the prolific growth of poppies, camomile and charlock on the Somme battlefield from latent seeds brought to the surface by shell fire is mentioned. Charlock, Sinapis arvensis, appeared on earth thrown up by shells and in shell craters, when there was no trace of it on the undisturbed ground; this may be readily appreciated when we read that seeds of charlock may retain their vitality for forty years when buried in the soil.

Instances of gorse seeds, Ulex europaus, which retained their vitality for forty, twenty-five and twenty years in the soil, and seeds of acacia, foxglove, campanula, etc., which grew after being buried for many years are described, but the most interesting account is that of Nelumbo, the Japanese lotus or sacred lotus of India. "Probably the record longevity for any seed is that recorded by Ohga who obtained approximately 100 per cent germination with 'seeds' of Nelumbo nucifera, Gaertn. which he found on a peat bed buried two feet deep with loess in the Pulantien river valley in Southern Manchuria, the bed being $12 \frac{1}{2}$ metres above the present water level of the river. Judging by the age of trees of Salix babylonica on the bed of this former lake and from the rate of lowering of the water level, it is probable that the 'seeds' are at least 120 years old and may be 400 years old or even older, judging by the rate of erosion." Ohga gave thirty of the "seeds" to the British Museum, and in 1931, at the request of Sir Arthur Hill, the British Museum authorities sent two of these "seeds", which they had germinated, to Kew. The seedlings were planted in the Victoria Regia pool and flowered during August 1932. "Apart from the smaller flowers and seed vessels, there was nothing to distinguish them from Nelumbo nucifera, Gaertn. raised from recent 'seed'."

In 1879 Beal mixed seeds with sand and buried them in bottles. The results of this experiment show that after fifty years, seeds of Brassica, Enothera, Polygonum, Rumex and Verbascum are capable of germination. Duvel experimented under more natural conditions, mixing the seeds with soil and using earthenware pots covered with porous saucers. It was found that of 107 species, 51 grew after being buried for twenty years. Shull found that seeds of many land and water plants would germinate after immersion in mud and water for periods of four to seven years. Some seeds will even withstand the action of salt water for considerable periods.

Various experiments made over a period of more than a hundred years with seeds stored in museums and herbaria are described by $\mathrm{Mr}$. Turner, including the 150-year old seeds of Nelumbium [Nelumbo] speciosum in the British Museum, which Robert Brown germinated in $\mathbf{1 8 5 0 ,}$ Ewart's success with 105-year old seeds of Goodia lotifolia in Australia, Becquerel's 87-year old seeds of Cassia bicapsularis in the Herbarium of the Natural History Museum of Paris, and Turner's experiments in 1932 with seeds from dated bottles in the Kew museums. Anthyllis Vulneraria and Trifolium striatum, both 90 years old, gave a germination of 4 and $14 \cdot 1$ per cent respectively. "The seedlings are now growing in one of the houses at Kew." Ewart formed the opinion that "However dry the seeds may be they cannot indefinitely prolong their vitality. Even the most resistant seeds after 50 to 100 years show a pronounced decrease in the percentage germination, and the general trend of the curves is such as to show that the probable extreme duration of vitality for any known seed may be set between 150 and 250 years (Leguminose).",

Heldreich suggests that the sudden appearance, in the Laurion area (Greece), of Silene juvenalis and a supposed new species which he named Glaucium Serpieri was due to their seeds having remained buried for more than fifteen hundred years in the soil under the heaps of old mining débris. When the débris was removed, the 
seeds sprang into life again. A taxonomic investigation made by Dr. Turrill has shown that Silene juvenalis is conspecific with $S$. subconica, a not uncommon species in the countries around the Agean Sea. There is nothing in the taxonomy or distribution of S. subconica and Glaucium Serpieri, which has been shown by Turrill to be $G$. flavum var. leiocarpum, to make it improbable for them to occur naturally in the Laurion district, and in all probability both species were in the neighbourhood before the heaps of débris were removed, and simply spread on the vacated and denuded ground in the absence of close competition. "The evidence is all against either Glaucium or Silene at Laurion being examples of long enduring seed dormancy."

In spite of research, popular belief clings tenaciously to the fairy tales concerning the germination of seeds from ancient tombs, which newspapers and broadcasting have unwittingly circulated. Stories of seed germination after a dormancy of thousands of years have even been used as an illustration of immortality. The reply to this curious notion deserves to be quoted in full :-_"There is no authenticated evidence that wheat taken from undisturbed Egyptian tombs will germinate. An experiment was made at Kew some thirty years ago with grain from a model granary, found in a tomb of the 19th dynasty and brought to England by Sir E. A. Wallis Budge. Samples were tested under various conditions and the effect of coloured glass was tried in the effort to induce germination, but after three months the grain had turned to dust. Percival states 'I examined a number (of grains) found by Prof. Flinders Petrie in the Græco-Roman cemetery at Hawara (about first century B.c.). . . the embryo had become dark brown, its plumule greatly shrivelled and little of its structure was visible." "In grain from a tomb of the 18th dynasty, 1400 B.c., 'all the parts were more brittle and the embryo more completely disorganised than in the grains from Hawara. It is scarcely necessary to observe that the embryos were dead. Prof. Petrie tested samples of grain of Græco-Roman age which he found at Hawara immediately after exhumation. The grains were sown on the banks of a canal in varying degrees of moisture . . . but none germinated." "According to Gain, although Egyptian wheat and barley often have an exterior appearance of good preservation, the embryo has undergone a marked chemical change and is no longer viable. This change shows that the dormant life of the grain has long been extinct."

"Sir E. A. Wallis Budge has accounted for the popular belief in the germination of grain from Egyptian tombs and explains that for hundreds of years the natives of Egypt have used the halls of tombs for the wheat and barley obtained from Syria. Ancient coffins have been packed in this Syrian wheat and sent to England, and sueh grains will, of course, grow. During the last 30 years the native dragoman and guides have found that tourists will buy 'mummy wheat' and they keep supplies in the tombs, carefully hidden, which they dig up under the eyes of the astonished visitor and offer as 'mummy wheat' or 'mummy barley'."

It is amusing to know that the guides sometimes 'find' grains of maize in Egyptian tombs in order to supply the credulous tourist, forgetting that maize was unknown until the discovery of America, whilst some of their faked wheat samples produce plants suspiciously identical with the improved wheat varieties grown in Egypt at the present time.

"Cereals are ill adapted for a prolonged period of quiescence. Sifton has shown that Canadian wheat may retain its vitality for 18 years, and that the longevity of oats is greater than that of wheat, possibly owing to the protection of the hulls. Nineteen-year old kernels of oats gave a germination of 41 per cent. Percival records an exceptional case of wheat remaining viable for twenty-five years. White found that in Australia the germination of wheat is lost after 11-16 years and that of barley after 8-10. Fanciful tales are current with regard to 'miracle' or 'mummy' wheat, Triticum, turgidum var. mirabile Körn and 'mummy peas', Pisum sativum var. umbellatum (Mill.) Ser."

It may be of interest to mention here that a branched form of Triticum turgidum has been grown for many years in America under the various names of 'Alaska', 'Many Spiked', 'Seven-Headed', 'Multiple-Headed', 'Egyptian', 'Miracle', 'Mummy', 'Wheat 3,000 Years Old', etc. These last four names are derived from an untrue story which tells that when the coffin of an Egyptian mummy was opened, some wheat was found. The seeds were planted, but only a single grain grew. The resulting plant proved a wonderful yielder and very different from any wheat now grown. It seems quite natural that if an unbranched head will yield so much, a branched head should yield much more. Actually the branched heads contain more grains than the unbranched heads of ordinary varieties, but as there are far fewer heads per acre, the yields are naturally less. A branched form of Triticum turgidum has been tried in the British Isles, but its general produce does not warrant its cultivation here, for it is inferior both in yield and quality.

"Miracle wheat is the commonest branched form of Triticum turgidum met with in South Europe and the North African coast. It is usually cultivated as a curiosity. Fasciated forms of the pea, similar to the so-called mummy pea, are figured by Tabernæmontanus in his Herbal published in 1590, and Miller in his Gardeners' Dictionary, 8th edit., 1771, described the form under the name of Pisum umbellatum, rose or crown pea. The misleading name of mummy pea is equally applied to the non-fasciated form, sometimes grown in cottage gardens. It is popularly asserted that miracle wheat and mummy peas originate from Egyptian tombs and that such seeds germinate when sown, but in every instance the statements prove to be without foundation." 